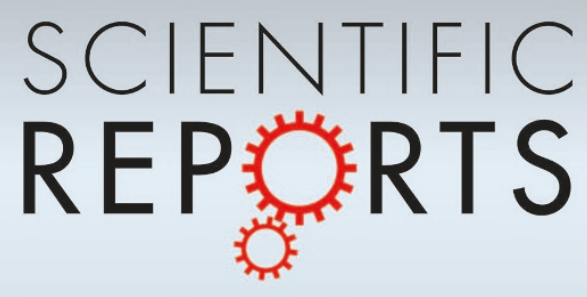

OPEN

SUBJECT AREAS:

BIOLOGICAL

TECHNIQUES

ENVIRONMENTAL SCIENCES

ENVIRONMENTAL SOCIAL SCIENCES

Received

11 October 2013

Accepted

20 January 2014

Published

5 February 2014

Correspondence and requests for materials should be addressed to

Y.G.C. (yg2chen@ yahoo.com)

\section{Enhanced Bio-hydrogen Production from Protein Wastewater by Altering Protein Structure and Amino Acids Acidification}

Type

Naidong Xiao, Yinguang Chen, Aihui Chen \& Leiyu Feng

State Key Laboratory of Pollution Control and Resource Reuse, School of Environmental Science and Engineering, Tongii University, Shanghai 200092, People's Republic of China.

Enhanced bio-hydrogen production from protein wastewater by altering protein structure and amino acids acidification type via $\mathrm{pH}$ control was investigated. The hydrogen production reached $205.2 \mathrm{~mL} / \mathrm{g}$-protein when protein wastewater was pretreated at $\mathrm{pH} 12$ and then fermented at $\mathrm{pH} 10$. The mechanism studies showed that $\mathrm{pH} 12$ pretreatment significantly enhanced protein bio-hydrolysis during the subsequent fermentation stage as it caused the unfolding of protein, damaged the protein hydrogen bonding networks, and destroyed the disulfide bridges, which increased the susceptibility of protein to protease. Moreover, $\mathrm{pH}$ 10 fermentation produced more acetic but less propionic acid during the anaerobic fermentation of amino acids, which was consistent with the theory of fermentation type affecting hydrogen production. Further analyses of the critical enzymes, genes, and microorganisms indicated that the activity and abundance of hydrogen producing bacteria in the $\mathrm{pH} 10$ fermentation reactor were greater than those in the control.

ydrogen has been deemed the future energy carrier due to its high energy content and the lack of a greenhouse effect. The use of biotechnology to produce hydrogen is becoming an important strategy and attracting the attention of many researchers as it is a sustainable alternative compared to conventional hydrogen production methods ${ }^{1,2}$. Bio-hydrogen production by dark fermentation is a process in which anaerobic bacteria use organic wastes to produce hydrogen in the absence of a light source ${ }^{3}$. This process has several benefits with respect to the environment such as energy recover and resource reuse $e^{4}$. Additionally, it has a high hydrogen production rate with a simple reactor configuration ${ }^{5}$.

Dark fermentative hydrogen can be produced from many organic wastes, such as wastewater. Carbohydrate in wastewater often accounts for the majority of the organic load to produce bio-hydrogen in the literature ${ }^{6}$. Nevertheless, protein is also the main organic substrate in some wastewaters. For example, the wastewaters generated during the productions of abattoir, whey, cheese, casein, fish, and silk usually contain significant amount of protein ${ }^{7,8}$. As seen in Figure 1 during anaerobic fermentation protein is firstly hydrolyzed to peptides and amino acids by extracellular enzyme (step-I), and then fermented to volatile fatty acids and hydrogen (stepII). Unlike carbohydrates, protein has a unique three-dimensional structure. Usually, the step-I is very slow as protein is unsusceptible to protease cleavage in its native folded conformation ${ }^{9,10}$. Thus, hydrolysis is the ratelimiting step during hydrogen production from protein wastewater.

Although it has been reported that bio-hydrogen can be produced from protein wastewater via anaerobic dark fermentation at neutral $\mathrm{pH}$, the reported maximal hydrogen yield is less than $20 \mathrm{~mL} / \mathrm{g}$-protein at a protein concentration of $2 \mathrm{~g} / \mathrm{L}^{211,12}$. Moreover, in all these studies the hydrogen-producing substrate was peptone, which was formed during partial hydrolysis of protein and was distinguished from protein on the basis of size and threedimensional structure. The hydrolysis rate of protein could be accelerated by the change of its folded structure, which however, has never been documented in previous studies. In addition, previous studies found that the fermentation $\mathrm{pH}$ is an important factor affecting bio-hydrogen production, and the optimal $\mathrm{pH}$ for bio-hydrogen production from protein-rich waste (such as sewage sludge) is alkaline $\mathrm{pH}$ (about 8.5-10) owing to the improved solubilization of sludge organic matters and the inhibitory effect on hydrogen consuming microorganisms ${ }^{2,13}$, but the impacts of $\mathrm{pH}$ on protein structure and protein hydrolyzate (amino acids) conversion involved in step-II during hydrogen production from protein wastewater have seldom been investigated. 


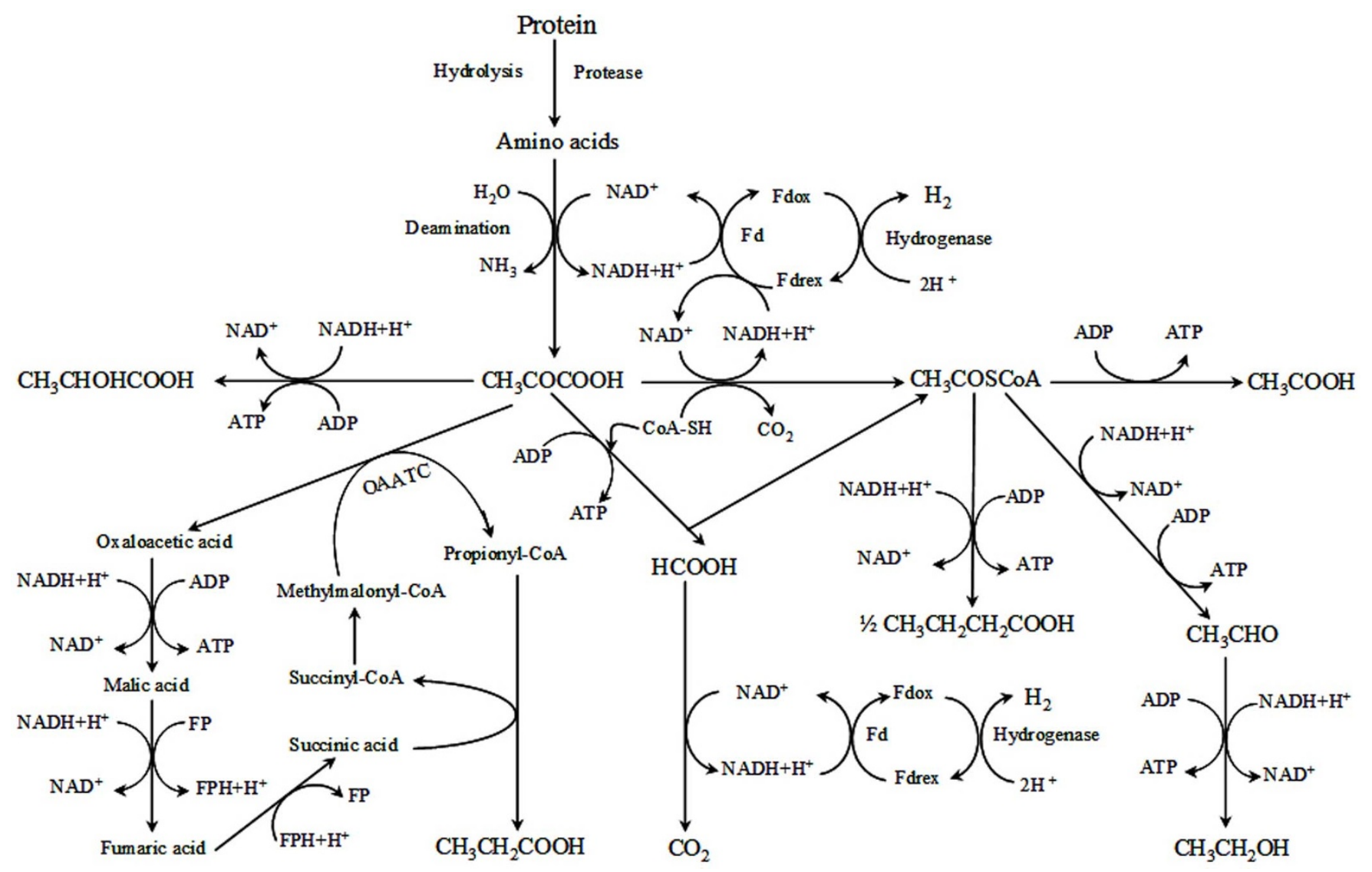

Figure 1 | Proposed metabolic pathway for anaerobic bio-hydrogen production from protein.

In this study a new method (i.e., pretreating protein wastewater at $\mathrm{pH} 12$ and then fermenting it at $\mathrm{pH} 10$ ) for enhancing bio-hydrogen production from protein wastewater by altering protein structure and amino acids acidification type was reported. Firstly, the effects of different pretreatment and fermentation $\mathrm{pH}$ values on the production of bio-hydrogen from protein wastewater were studied. Then, the reasons for $\mathrm{pH} 12$ pretreatment and $\mathrm{pH} 10$ fermentation showing significantly higher hydrogen production were explored by advanced analytical techniques from the aspects of protein unfolding, protein hydrogen bonding networks damage, disulfide bridge breakage, the reactions of amino acids fermentation type, critical enzyme activity and genes, and key microbes.

\section{Results}

Effects of pretreatment and fermentation $\mathrm{pH}$ on bio-hydrogen production. In this study the influence of pretreatment $\mathrm{pH}$ on fermentative hydrogen production was investigated firstly. It was observed that the hydrogen production from synthetic protein wastewater was increased with fermentation time between 12 and $72 \mathrm{~h}$ (Figure 2A), which, however, was not significantly enhanced when the time was further prolonged to $84 \mathrm{~h}(p>0.05)$. The comparison of pretreatment $\mathrm{pH}$ values affecting hydrogen production was therefore made at fermentation time of $72 \mathrm{~h}$. It can be seen from Figure $2 \mathrm{~A}$ that $\mathrm{pH} 12$ or $\mathrm{pH} 12.5$ pretreatments resulted in a much higher hydrogen production than other $\mathrm{pHs}$ and the control $(\mathrm{pH} 7)$ at a fermentation time of $72 \mathrm{~h}$. Nevertheless, there was no significant difference in the hydrogen production between $\mathrm{pH} 12$ and $\mathrm{pH} 12.5$ pretreatments $(p>0.05)$. Thus, the optimal pretreatment $\mathrm{pH}$ was 12 under the condition of fermentation $\mathrm{pH} 7$.

The hydrogen production was also observed to be significantly affected by fermentation $\mathrm{pH}$. With the use of $\mathrm{pH} 12$ pretreated wastewater as the substrate the time courses of hydrogen production being affected by fermentation $\mathrm{pH}$ are shown in Figure 2B. There was no detectable hydrogen produced at fermentation $\mathrm{pH} 4$ and $\mathrm{pH} 11$. Although bio-hydrogen was produced between $\mathrm{pH} 5$ and $\mathrm{pH} 10$, the maximal hydrogen production and suitable fermentation time were different. In the $\mathrm{pH}$ range of 6-10 the optimal fermentation time was $72 \mathrm{~h}$, whereas it was $96 \mathrm{~h}$ at pH 5 (statistical analysis is shown in Table S1). The hydrogen production at optimal fermentation time was respectively $155.6(\mathrm{pH} \mathrm{5),} 155.7(\mathrm{pH} \mathrm{6)}, 117.1(\mathrm{pH} 7)$, $96.2(\mathrm{pH} \mathrm{8}), 162.8(\mathrm{pH} 9)$, and $205.2(\mathrm{pH} \mathrm{10)} \mathrm{mL} / \mathrm{g}$-protein. Obviously, the maximal hydrogen production from $\mathrm{pH} 12$ pretreated synthetic protein wastewater occurred at fermentation $\mathrm{pH} 10$.

Effects of $\mathrm{pH} 12$ pretreatment on the characters of protein wastewater. During $\mathrm{pH} 12$ pretreatment there was no significant change in the concentration of protein $(p>0.05)$, and no hydrogen was generated. However, $\mathrm{pH} 12$ pretreatment significantly changed the characters of protein wastewater. In this study the influence of $\mathrm{pH} 12$ pretreatment on the $\alpha$-helix content of protein molecule was firstly investigated by circular dichroism. Compared with the control, as seen in Figure $3 \mathrm{~A}, \mathrm{pH} 12$ pretreatment induced a significant decrease in the $\alpha$-helix content of protein from $69.1 \%$ to $42.4 \%$. The effect of $\mathrm{pH} 12$ pretreatment on the hydrodynamic diameter of protein was further investigated with BSA as a model protein. The data in Figure $3 \mathrm{~B}$ showed that the average hydrodynamic diameter of BSA was $8.0 \mathrm{~nm}$ in the control ( $\mathrm{pH} 7$ pretreatment), while it was increased to $12.3 \mathrm{~nm}$ after $\mathrm{pH} 12$ pretreatment.

Protein has endogenous fluorescence since it contains aromatic amino residues, and the numbers of tryptophan, tyrosine and phenylalanine residues in the BSA molecule are 2, 21 and 26, respectively ${ }^{14}$. The effect of $\mathrm{pH} 12$ pretreatment on the changes of protein structure was further assayed by EEM fluorescence spectroscopy, which had been applied as a useful and powerful methodology to extract information about the structural features of protein ${ }^{15}$. As seen 

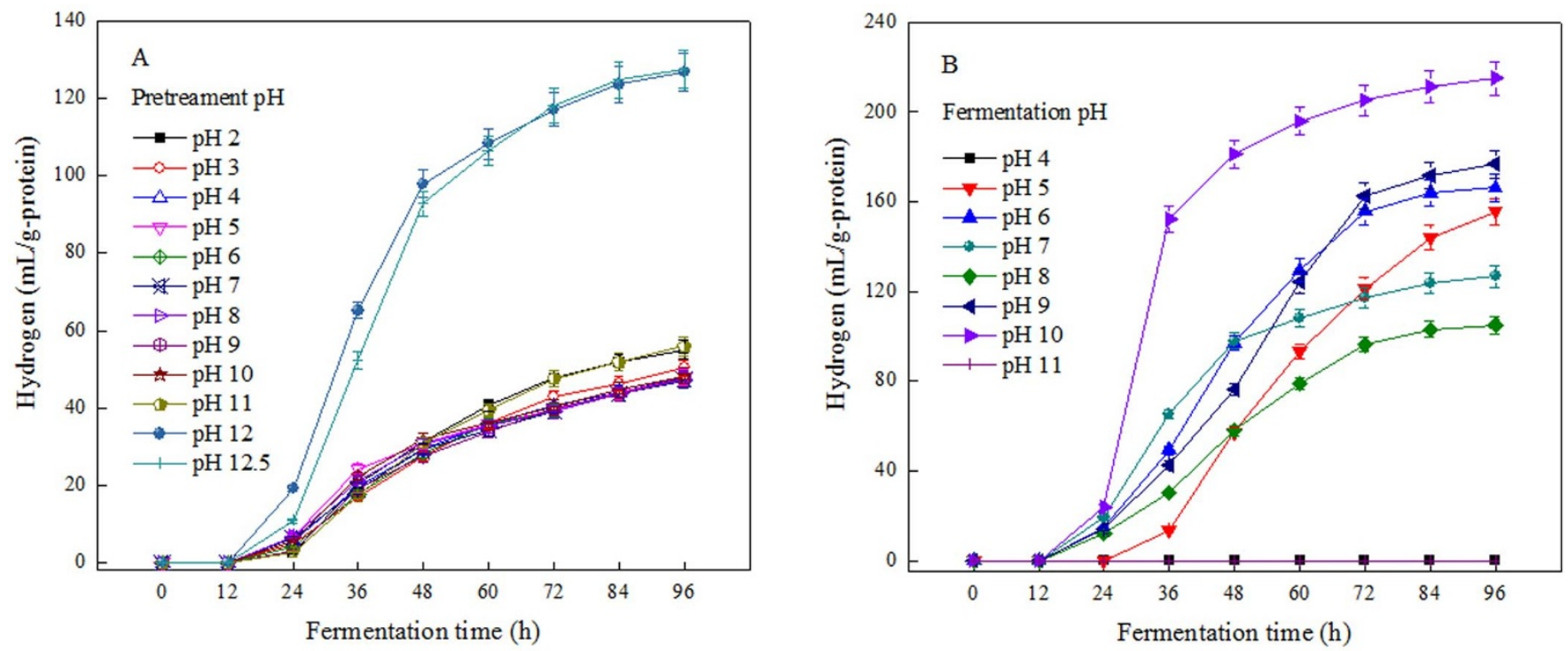

Figure 2 The time courses of effects of pretreatment $\mathrm{pH}(\mathrm{A})$ and fermentation $\mathrm{pH}(\mathrm{B})$ on the accumulated hydrogen production. The fermentation $\mathrm{pH}$ was 7 (A) and pretreatment $\mathrm{pH}$ was 12 (B). Error bars represent standard deviations of triplicate tests.

in Figure 4 the fluorescence maximum peak intensity of BSA in the control test was $5.18 \times 10^{6}$ a.u., which was sharply dropped to $1.79 \times$ $10^{6}$ a.u. after $\mathrm{pH} 12$ pretreatment. Obviously, $\mathrm{pH} 12$ pretreatment caused considerable decrease in the fluorescence intensity of protein. At the same time the maximum excitation and emission wavelengths of protein were shifted after $\mathrm{pH} 12$ pretreatment, i.e., the excitation was $272 \mathrm{~nm}$ and emission was $350 \mathrm{~nm}$ in the control, while the corresponding data were $278 \mathrm{~nm}$ and $340 \mathrm{~nm}$ for the $\mathrm{pH} 12$ pretreated protein. It implied that the main reason for $\mathrm{pH} 12$ pretreatment resulting in the decrease of fluorescence intensity was due to the quenching of aromatic residues fluorescence since there was a significant shift in the fluorescence maximum ${ }^{16}$.

Protein structure is influenced and stabilized to a great extent by disulfide bridges. Raman spectroscopy has been employed extensively to probe the conformation of disulfide bridges in protein because the frequency of S-S stretching mode of the disulfide bridge is sensitive to its conformation ${ }^{17}$. Raman spectra of the control and $\mathrm{pH} 12$ pretreated BSA in the $200-1800 \mathrm{~cm}^{-1}$ region after being normalized against the phenylalanine band at $1004 \mathrm{~cm}^{-1}$ are shown in Figure S1 (Supplementary information). The region of 500$550 \mathrm{~cm}^{-1}$ in the Raman spectrum belongs to the stretching vibration mode of S-S bridges, and the peaks appearing around 500-510, 515525 , and $535-545 \mathrm{~cm}^{-1}$ are the features of the gauche-gauche-gauche (ggg), gauche-gauche-trans (ggt), and trans-gauche-trans (tgt) conformation, respectively ${ }^{17,18}$. According to the curve fitting of the band, the conformations of 17 disulfide bridges in BSA can be determined. The analyses of S-S Raman bands of BSA before and after $\mathrm{pH}$ 12 pretreatment are illustrated in Figure 5. The main conformation of BSA in the control was ggg $\left(506 \mathrm{~cm}^{-1}\right.$, Figure $\left.5 \mathrm{~A}\right)$. pH 12 pretreatment decreased the relative intensity of S-S Raman bands and meanwhile induced a prominent increase of ggt conformation of disulfide bridges (Figures 5B). Figure 5C shows the composition of the S-S bridge conformations of BSA after $\mathrm{pH} 12$ pretreatment. There were respectively 11, 3 and 3 out of 17 disulfide bridges of BSA with the ggg, ggt and tgt conformations in the control, which were 3,6 , and 2 after $\mathrm{pH} 12$ pretreatment.
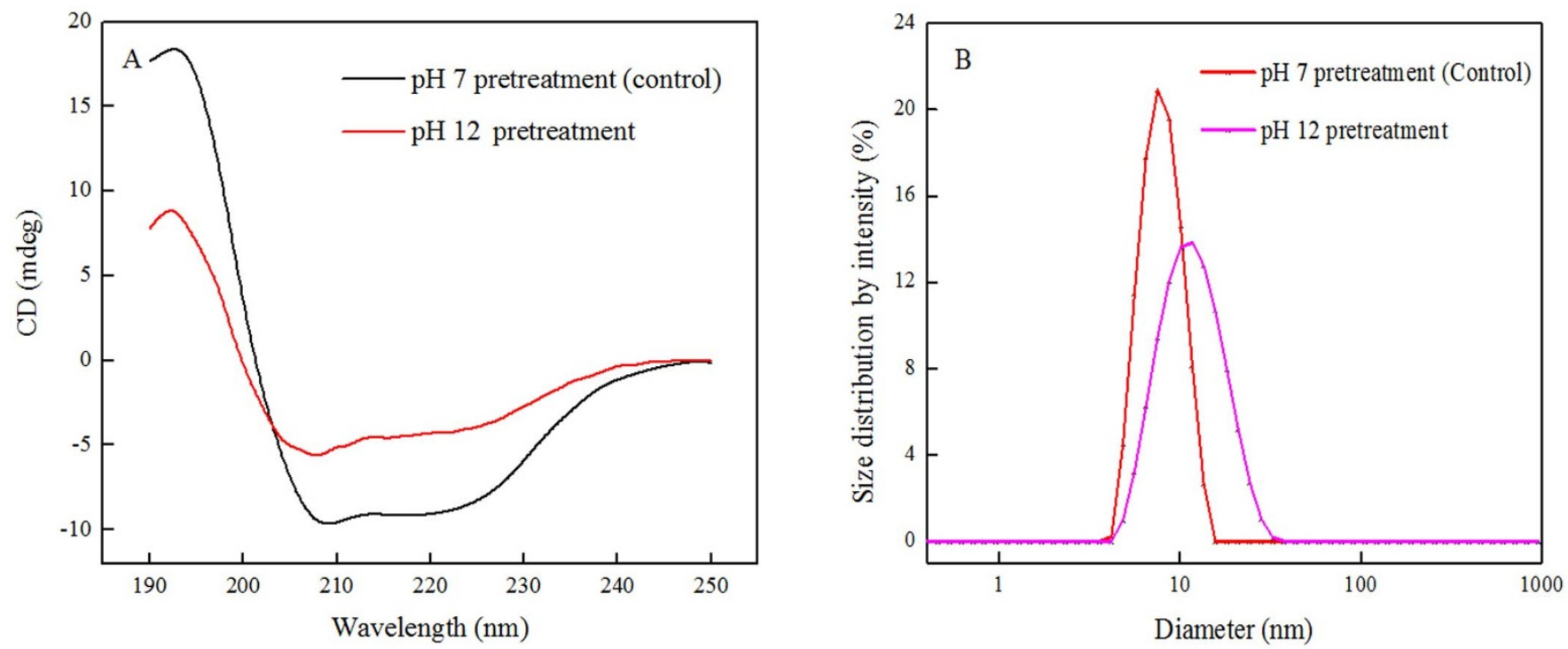

Figure 3 Effects of $\mathrm{pH} 12$ pretreatment on the CD spectra and hydrodynamic diameter of protein. 

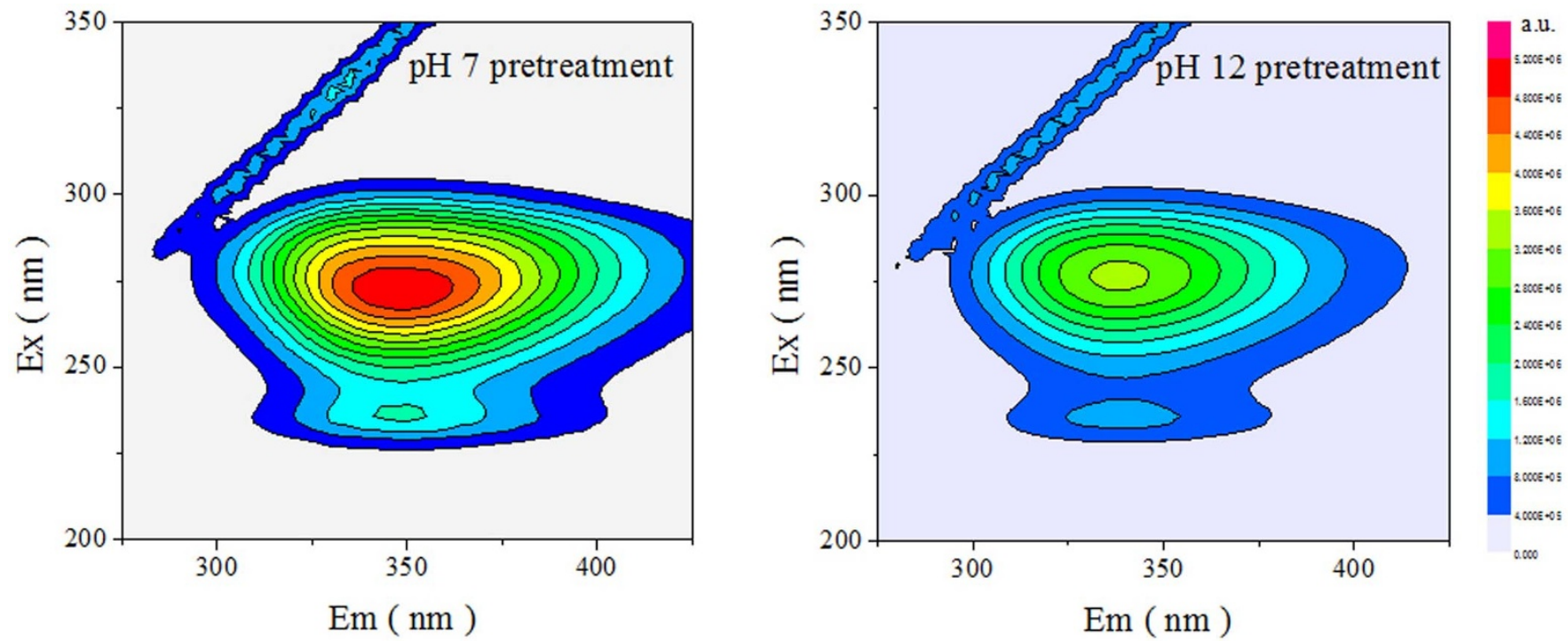

Figure $4 \mid$ Effects of $\mathrm{pH} 12$ pretreatment on the fluorescence spectra of protein wastewater.

Effects of $\mathrm{pH} 12$ pretreatment on the susceptibility of protein to protease and protein hydrolysis efficiency. To investigate the effects of $\mathrm{pH} 12$ pretreatment on the susceptibility of protein to protease, the protein enzyme hydrolysis experiments were conducted, and the protein enzymolysis efficiency was used to express the susceptibility of protein to protease. As seen in Figure 6A the protein enzymolysis efficiency of synthetic protein wastewater was significantly affected by $\mathrm{pH} 12$ pretreatment. After enzymolysis for $1 \mathrm{~h}$, the protein enzymolysis efficiency with the $\mathrm{pH} 7$ pretreated wastewater was only $39.9 \%$, whereas it was significantly increased to $71.9 \%$ with the $\mathrm{pH} 12$ pretreated one.

As seen in Figure 6B the hydrolysis of protein during anaerobic hydrogen production was significantly affected by $\mathrm{pH} 12$ pretreatment. The hydrolysis efficiency in the control ( $\mathrm{pH} 7$ pretreatment) was only $28.8 \%$, whereas it bacame $86.7 \%$ after the wastewater was pretreated at $\mathrm{pH} 12$. Further investigation showed that during fermentation for hydrogen production the activity of protease was also remarkably improved after the protein wastewater was pretreated by pH 12 (Figure 6B).

Effects of pH 10 fermentation on amino acids conversion. From the proposed metabolic pathway illustrated in Figure 1 it can be seen that the hydrogen production from protein wastewater comes from the conversion of amino acids to volatile fatty acids. Thus, the synthetic amino acids wastewater was used to further investigate the influence of $\mathrm{pH} 10$ fermentation on bio-hydrogen production. As shown in
Figure S2A (Supplementary information) the hydrogen generation in the $\mathrm{pH} 7$ (control) fermentation test of synthetic amino acids wastewater was much lower than that in the $\mathrm{pH} 10$ one (63.1 versus $139.9 \mathrm{~mL} / \mathrm{g}$-amino acids). The data in Figure S2A indicated that the concentration of VFA at fermentation $\mathrm{pH} 7$ test was slightly higher than that at fermentation $\mathrm{pH} 10(2166.8$ versus $1836.4 \mathrm{mg}$ $\mathrm{COD} / \mathrm{L})$. However, the concentration and percentage of acetic acid in $\mathrm{pH} 10$ reactor were significantly greater than those in $\mathrm{pH} 7$ reactor (940.0 against $572.0 \mathrm{mg} \mathrm{COD} / \mathrm{L}$, and $51.2 \%$ versus $26.4 \%$ ), and the opposite observations were made with propionic acid (207.0 against $632.8 \mathrm{mg} \mathrm{COD} / \mathrm{L}$, and $11.3 \%$ versus $29.2 \%$, see Figure S2B).

Effects of pH 12 pretreatment plus pH 10 fermentation on the activities of key enzymes and microorganisms during hydrogen production. According to the supposed metabolic pathway for biohydrogen production from protein (Figure 1), the NADH-Fd reductase and hydrogenase are the key metalloenzyme responsible for hydrogen formation. To recycle $\mathrm{NAD}^{+}, \mathrm{NADH}$ is oxidized by $\mathrm{NADH}-\mathrm{Fd}$ reductase, while hydrogenase oxidizes reduced ferredoxin to produce molecular hydrogen ${ }^{19,20}$. Oxaloacetate transcarboxylase (OAATC) is a key enzyme involved in propionic acid synthesis and NADH consumption ${ }^{21}$. As illustrated in Figure 7A the relative activity of NADH-Fd reductase and hydrogenase was improved by $34 \%$ and $71 \%$ when the wastewater fermentation $\mathrm{pH}$ changed from $\mathrm{pH} 7$ to $\mathrm{pH} 10$. The OAATC, however, was significantly restrained to $58.5 \%$ of the control at fermentation $\mathrm{pH} 10$. Then
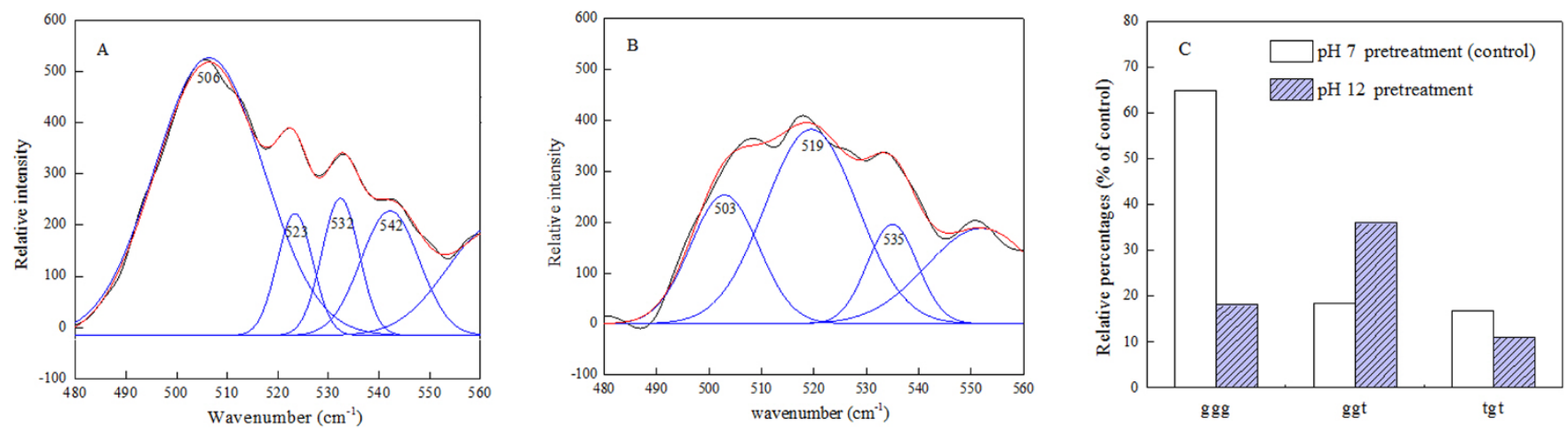

Figure 5 Curve fitting of the S-S Raman band of $\mathrm{pH} 7$ pretreated (A) and $\mathrm{pH} 12$ pretreated (B) BSA, and the composition of S-S bridge conformations (C) of BSA by the analysis of the $480-560 \mathrm{~cm}^{-1}$ Raman regions. Black line: experimental spectrum; red line: the fitting curve; blue line: peaks. 

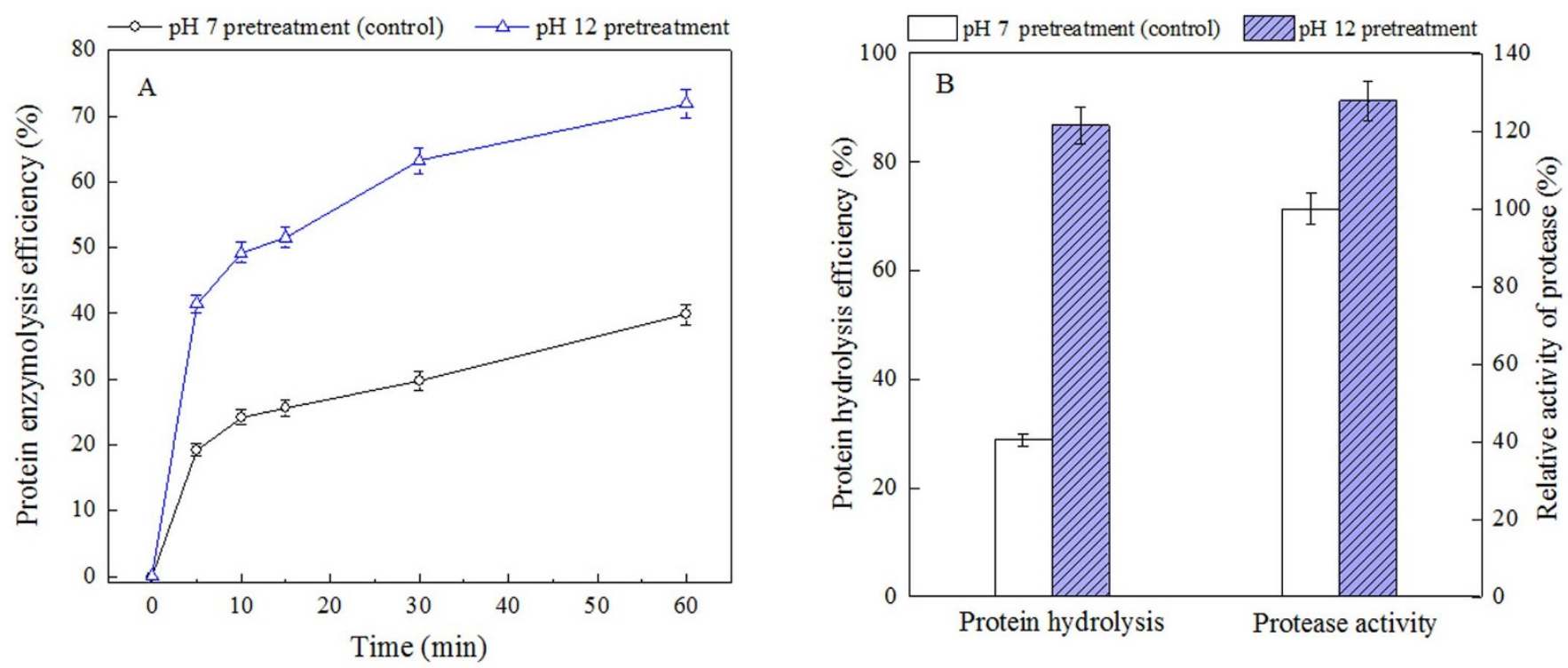

Figure 6 Effects of $\mathrm{pH} 12$ pretreatment on the susceptibility of protein to protease (A), and the protein hydrolysis efficiency during protein wastewater anaerobic fermentation for hydrogen production at $\mathrm{pH} 7$ for $72 \mathrm{~h}(\mathrm{~B})$. The concentration of pronase E in the synthetic protein wastewater was $50 \mathrm{mg} / \mathrm{L}$ and the enzymolysis time was $1 \mathrm{~h}$. Error bars represent standard deviations of triplicate tests.

the real-time polymerase chain reaction (PCR) analysis (see Supplementary information of "Real-time PCR" and Table S2) was conducted to explore the intrinsic reason. As seen in Figure $7 \mathrm{~B}$ the expression of $\mathrm{Fd}$ (ferredoxin) gene in the $\mathrm{pH} 10$ fermentation reactor was about 1.44- fold of that in the control reactor. The same observation was made with the expression of hydA (Fe-hydrogenase) gene, which was 1.85-fold of the control when the anaerobic fermentation $\mathrm{pH}$ was 10. The fluorescence in situ hybridization (FISH) assay was conducted to investigate the influences of $\mathrm{pH} 10$ on the abundance of hydrogen producing bacteria (see Supplementary information of "Fluorescence in situ hybridization"). The images are shown in Figure 8. Further images analysis indicated that the abundance of hydrogen producing bacteria in $\mathrm{pH} 7$ and $\mathrm{pH} 10$ fermentation reactors was $24.5 \%$ and $32.1 \%$, respectively.

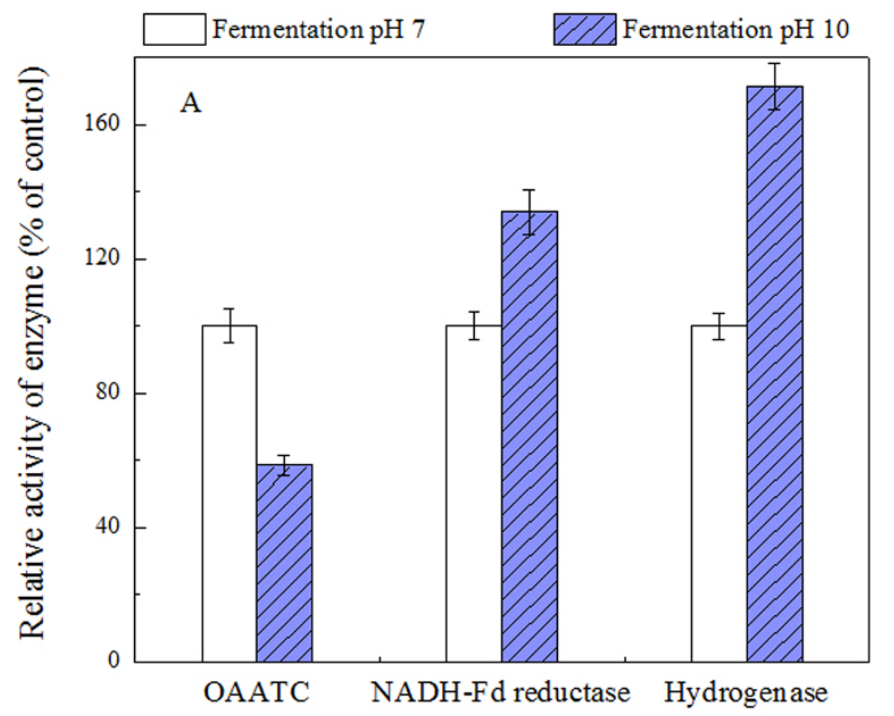

Hydrogen production from real protein wastewater enhanced by pH 12 pretreatment and pH 10 fermentation. The examination of applying $\mathrm{pH} 12$ pretreatment plus $\mathrm{pH} 10$ fermentation to enhance hydrogen production from whey protein wastewater, a real high protein content organic wastewater, was conducted. As seen in Figure S3A (Supplementary information) no matter whether the hydrogen production from whey protein wastewater pretreated or not was increased with fermentation time, the accumulative hydrogen production of control $(\mathrm{pH} 7$ pretreatment and $\mathrm{pH} 7$ fermentation) was only $44.8 \mathrm{~mL} / \mathrm{g}$-COD at fermentation time of $72 \mathrm{~h}$, while it was significantly improved to $106.9 \mathrm{~mL} / \mathrm{g}$-COD after the whey protein wastewater was pretreated at $\mathrm{pH} 12$ and fermented at $\mathrm{pH}$ 10. The same observations were made with the protein utilization efficiency and VFA production, which was increased

Figure 7 Comparison between $\mathrm{pH} 7$ and $\mathrm{pH} 10$ on the relative activities of OAATC, NADH-Fd reductase, and hydrogenase (A), and the expression of ferredoxin (Fd) and Fe-hydrogenase (hydA) gene during wastewater fermentation for hydrogen production (B). Error bars represent standard deviations of triplicate tests. 

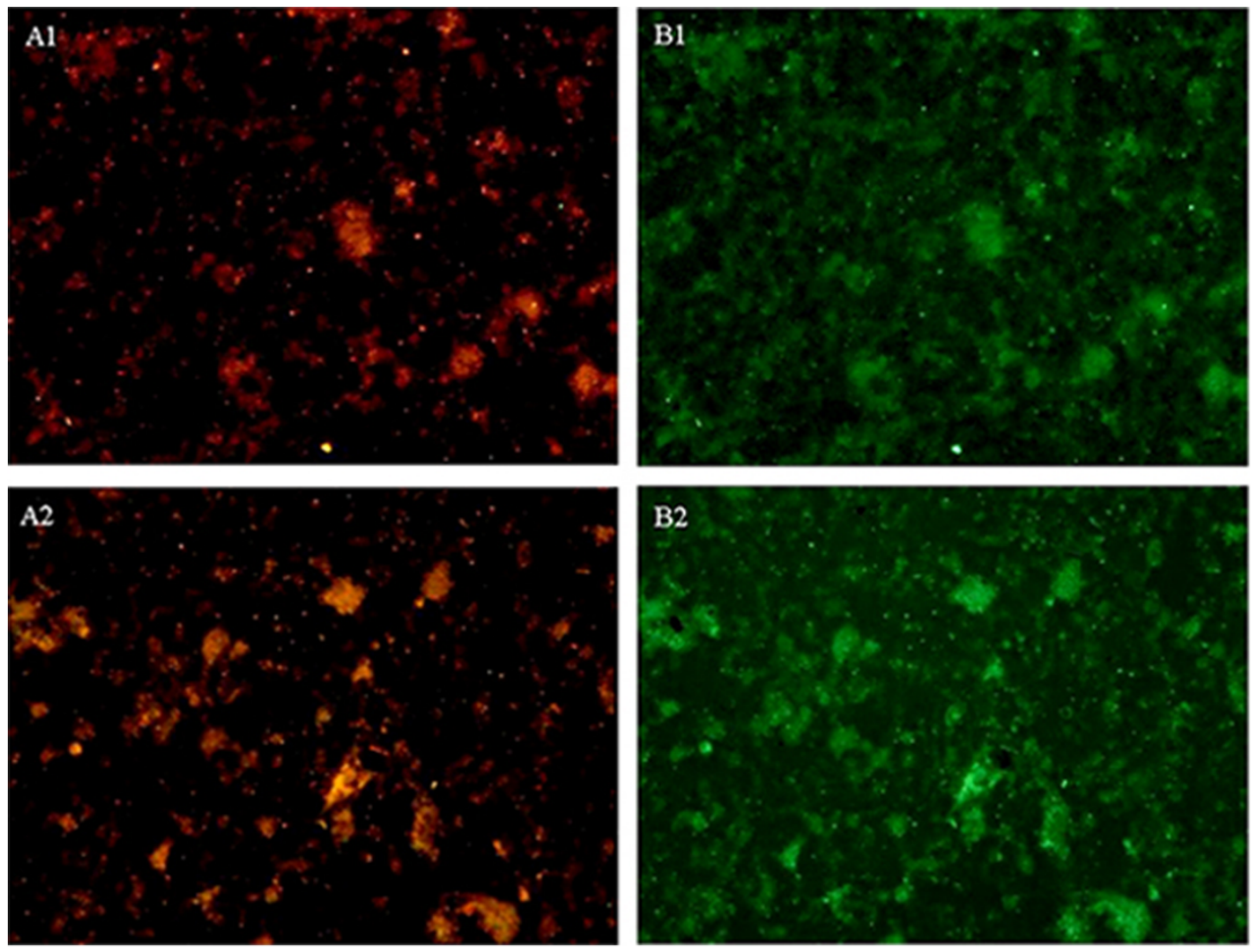

Figure $8 \mid$ Microscopy of sludge from the hydrogen production reactor of fermentation $\mathrm{pH} 7$ and fermentation $\mathrm{pH} 10$ at the time of $72 \mathrm{~h}$ by FISH $(\times 10)$. Hydrogen producing bacteria were labeled with HEX (yellow, A1 for $\mathrm{pH} 7$ and A2 for $\mathrm{pH} 10$ ), and domain bacteria were labeled with FITC (green, $\mathrm{B} 1$ for $\mathrm{pH} 7$ and $\mathrm{B} 2$ for $\mathrm{pH} 10)$.

respectively by $154 \%$ and $67 \%$ compared with the control (Figure S3B, Supplementary information).

\section{Discussion}

In the literature protein wastewater is directly fermented at approximately $\mathrm{pH} 7$ to produce hydrogen without any pretreatment, and the hydrogen yield is less than $20 \mathrm{~mL} / \mathrm{g}$-protein at a protein concentration of around $2.0 \mathrm{~g} / \mathrm{L}^{2,11}$. The data in Figure $2 \mathrm{~A}$ indicated that if the protein wastewater was unpretreated and directly fermented at $\mathrm{pH} 7$ (control) the bio-hydrogen production was $39.0 \mathrm{~mL} / \mathrm{g}$-protein, which was higher than the results of some previous studies because the the activity of homoacetogenesis was inhibited by $\mathrm{CHCl}_{3}$ in the current study. However, the hydrogen production was significantly increaed to $205.2 \mathrm{~mL} / \mathrm{g}$-protein when the protein wastewater was pretreated at $\mathrm{pH} 12$ and then fermented at $\mathrm{pH} 10$, which was more than 5-fold of the control. The reasons for $\mathrm{pH} 12$ pretreatment plus $\mathrm{pH} 10$ fermentation showing significantly higher bio-hydrogen production were explored and discussed next.

It is well known that under anaerobic fermentation conditions protein is firstly hydrolyzed to peptides and amino acids, and then fermented to volatile fatty acids and hydrogen (Figure 1). As the generation of hydrogen is relevant to the metabolism of protein, the influence of $\mathrm{pH} 12$ pretreatment on protein hydrolysis is investigated firstly. In this study it was observed that during $\mathrm{pH} 12$ pretreatment there was no significant change in the concentration of protein, which suggested that $\mathrm{pH} 12$ pretreatment did not directly cause the hydrolysis of protein.

The bio-hydrolysis behavior of protein has been reported to be affected by the changes of its secondary structure ${ }^{10,22}$. The $\alpha$-helix and $\beta$-sheet are the two main shapes in the secondary structure of protein, and the native BSA is dominated by $\alpha$-helix without $\beta$-sheet ${ }^{23}$. The decrease in $\alpha$-helix content of protein indicates the breakage of hydrogen bonding networks, which has been reported to be positively consistent with the degradation of protein $^{24,25}$. In this study $\mathrm{pH}$ 12 pretreatment induced a significant decrease in the $\alpha$-helix content of protein from $69.1 \%$ to $42.4 \%$ (Figure 3A), which was consistent with the results of protein hydrolysis efficiency during anaerobic fermentation (Figure 6B).

The unfolding of protein is often a prerequisite for its bio-hydrolysis ${ }^{9}$. Dynamic light scattering can probe the unfolding of protein by giving the size properties of protein in a three-dimensional structure $^{26}$. The unfolding of protein has been reported to play a critically important role in protein bio-hydrolysis by ATP-dependent protease as it influences the susceptibility of protein to proteases ${ }^{27}$. The data in Figure $3 \mathrm{~B}$ showed that $\mathrm{pH} 12$ pretreatment unfolded BSA from $8.0 \mathrm{~nm}$ to $12.3 \mathrm{~nm}$. The unfolding of protein would change the microenvironment of tryptophan, which could decrease protein fluorescence intensity and shift the fluorescence maximum ${ }^{15,28}$. This observation consistented with the changes of protein fluorescence after $\mathrm{pH} 12$ pretreatment (Figure 4). Then the unfolding of protein enhanced susceptibility of protein to proteases (Figure 6A) and the protease activity was therefore increased by almost $28 \%$ compared with the control (Figure 6B). Further investigation indicated that pretreating wastewater at $\mathrm{pH} 12$ not only destroyed the disulfide bridges of protein but changed their conformations (Figure 5). Thus the hydrolysis of protein during anaerobic fermentation was significantly increaced from $28.8 \%$ to $86.7 \%$ after the wastewater was pretreated at $\mathrm{pH} 12$. Since more protein was bio-hydrolyzed, more amino acids were provided for hydrogen producers, and the hydrogen production was increased.

As stated above, there was no hydrogen produced during $\mathrm{pH} 12$ pretreatment, and $\mathrm{pH} 12$ pretreatment did not cause protein hydrolysis directly. However, it significantly altered protein structure and the alteration remained stable when the $\mathrm{pH}$ was adjusted to $\mathrm{pH} 10$ for 
bio-hydrogen production (see Table S3 for details). But it should be emphasized that during protein wastewater fermentation the hydrogen is generated in the process of amino acids being bio-converted to volatile fatty acids, and there is no hydrogen generated when protein is hydrolyzed to amino acids. In this study the maximal hydrogen production from protein wastewater occurred at fermentation $\mathrm{pH}$ 10 , and the dynamic of hydrogen (Figure 2) was in line with that of ammonia (Figure S4), which was generated during the conversion of amino acids to volatile fatty acids by the reaction of deamination. The amino acids synthetic wastewater was further used to investigate the influence of $\mathrm{pH} 10$ fermentation on bio-hydrogen production. The data in Figure S2A showed that the hydrogen generation from amino acids wastewater in the $\mathrm{pH} 7$ (control) fermentation test was much lower than that in the $\mathrm{pH} 10$ one, which consistented with the result of higher hydrogen production at fermentation $\mathrm{pH} 10$ observed in Figure 2B. At the same time, as illustrated in Figure S2A the concentration of volatile fatty acids produced from amino acids at fermentation $\mathrm{pH} 7$ and $\mathrm{pH} 10$ was 2166.8 and $1836.4 \mathrm{mg}$ $\mathrm{COD} / \mathrm{L}$, respectively. It implied that the difference of hydrogen production from amino acids at fermentation $\mathrm{pH} 7$ and $\mathrm{pH} 10$ was not owing to the utilization efficiency of substrate but to the different anaerobic biochemical reactions.

Under anaerobic conditions the evolution of hydrogen through a NADH pathway is driven by the necessity of reoxidizing the residual $\mathrm{NADH}$ of metabolic reactions as $\mathrm{NADH}+\mathrm{H}^{+} \rightarrow \mathrm{NAD}^{+}+\mathrm{H}_{2}{ }^{29}$. As shown in Figure 1, there is $1,-2$, and 0 molecules residual NADH produced when one molecule pyruvate is respectively converted to acetic, propionic, and butyric acid, which indicates that higher hydrogen production corresponds to greater acetic acid but less propionic acid generation. It should be noted that the generation of butyric acid has no connection with the production of hydrogen but only contributes to reoxidation of NADH. There was no detectable ethanol and lactic acid produced in the current study. As seen in Figure S2B, the percentage of acetic acid in the $\mathrm{pH} 10$ fermentation reactor was significantly greater than that in the $\mathrm{pH} 7$ reactor $(51.2 \%$ versus $26.4 \%$ ), but the opposite observations was made with propionic acid (11.3\% versus $29.2 \%)$. Obviously, the result was in line with the theory of fermentation type affecting hydrogen production.

The NADH-Fd reductase and hydrogenase are the key enzymes to oxidize NADH and reduced ferredoxin to produce molecular hydrogen, while OAATC is a key enzyme for propionic acid synthesis ${ }^{19,20,21}$. As illustrated in Figure 7A pH 10 fermentaion improved the relative activitives of NADH-Fd reductase and hydrogenase, but it restrained the relative activitiy of OAATC compared with $\mathrm{pH} 7$ fermentaion. The real-time PCR further indicated that the expressions of Fd (ferredoxin) and hydA (Fe-hydrogenase) genes both were improved in the $\mathrm{pH} 10$ fermentation reactor (Figure 7B). The same observation was made with the abundance of hydrogen produing bacteria, which was increased from $24.5 \%$ (in the control reactor) to $32.1 \%$ (in the $\mathrm{pH}$ 10 fermentation reactor) according to the FISH results (Figure 8). It can be easily understood therefore that amino acids fermentation at $\mathrm{pH} 10$ had higher hydrogen production than that at $\mathrm{pH} 7$.

In summary, we presented a new strategy to significantly increase bio-hydrogen production from protein wastewater by altering protein structure and amino acids acidification type via $\mathrm{pH}$ control. The hydrogen production reached $205.2 \mathrm{~mL} / \mathrm{g}$-protein, which was much higher than that reported in the literature $2 . \mathrm{pH} 12$ pretreatment induced the unfolding of protein, damaged the protein hydrogen bonding networks, destroyed the disulfide bridges and changed their conformations, which increased the susceptibility of protein to protease and enhanced the hydrolysis of protein ${ }^{9}$. Moreover, when the fermentation $\mathrm{pH}$ varied from $\mathrm{pH} 7$ to $\mathrm{pH} 10$ the anaerobic metabolic reaction of amino acids shifted from propionic acid to acetic acid, and the critical enzyme activities and abundance of hydrogen producing bacteria were improved, which resulted in higher hydrogen yield in the fermentative reactor of $\mathrm{pH} 10$. Finally, the application of 12 pretreatment and $\mathrm{pH} 10$ fermentation to enhance bio-hydrogen evolution from real protein wastewater was testified to be feasible.

\section{Methods}

Experiments of pretreatment $\mathrm{pH}$ affecting hydrogen production from protein wastewater. The synthetic protein wastewater used in this study for bio-hydrogen production was prepared with bovine serum albumin (BSA, diagnostic grade power of BAH 68, obtained from Equitech-Bio) as carbon source, and its concentration was maintained at $2.0 \mathrm{~g} / \mathrm{L}$. The pretreatment was conducted in 12 identical reactors, each with working volume of $600 \mathrm{~mL}$, outside diameter of $85 \mathrm{~mm}$, height of $180 \mathrm{~mm}$, and cap of $25 \mathrm{~mm}$. For each reactor $300 \mathrm{~mL}$ protein wastewater was added and the $\mathrm{pH}$ value was adjusted to $2,3,4,5,6,7$ (control), 8, 9, 10,11,12, 12.5, respectively, by adding $6 \mathrm{M}$ hydrochloric acid $(\mathrm{HCl})$ or $6 \mathrm{M}$ sodium hydroxide $(\mathrm{NaOH})$ and maintained in an air-bath shaker $(100 \mathrm{rpm})$ with temperature of $21 \pm 1^{\circ} \mathrm{C}$ for $24 \mathrm{~h}$. There was no microorganism during the pretreatment of protein wastewater. After pretreatment, $1.0 \mathrm{~g} \mathrm{NaHCO}_{3}$ (buffer salt), $35 \mathrm{mg} \mathrm{K} \mathrm{HPO}_{4} \cdot 3 \mathrm{H}_{2} \mathrm{O}$ (phosphorus source), $1 \mathrm{~mL}$ trace element solution and $30 \mathrm{~mL}$ seed microorganism (see Supplementary Information for details) were added to each reactor. The mixture was then anaerobically fermented to produce hydrogen after its $\mathrm{pH}$ value was adjusted to 7 by adding $6 \mathrm{M} \mathrm{HCl}$ or $6 \mathrm{M} \mathrm{NaOH}$. According to the literature $60 \mathrm{ul} \mathrm{CHCl}_{3}(0.02 \%$, $\mathrm{V} / \mathrm{V}$ ) was added to the mixture to inhibit homoacetogenesis ${ }^{30}$. After being flushed with nitrogen gas for 2 min to remove oxygen, all reactors were capped with rubber stoppers, sealed and placed in an air-bath shaker $(140 \mathrm{rpm})$ with the temperature of $36 \pm 1{ }^{\circ} \mathrm{C}$. The total gas volume was measured by releasing the pressure in the reactor using a glass syringe $(100 \mathrm{~mL})$ to equilibrate with the room pressure according to the previous publication ${ }^{13}$. Gas was sampled with a $5 \mathrm{~mL}$ syringe for composition assay. As the $\mathrm{pH}$ value of protein wastewater was around 7 , the $\mathrm{pH} 7$ pretreated test could be regarded as the un-pretreated one.

Experiments of fermentation $\mathrm{pH}$ affecting hydrogen production from $\mathrm{pH} 12$ pretreated protein wastewater. The bio-hydrogen production experiments were conducted in 8 identical reactors with the $\mathrm{pH} 12$ pretreated protein wastewater as substrate. The fermentation $\mathrm{pH}$ in these 8 reactors was respectively $4,5,6,7,8,9,10$ and 11 and was kept constant by adding $6 \mathrm{M} \mathrm{HCl}$ or $6 \mathrm{M} \mathrm{NaOH}$ during the entire fermentation process. All other operations were the same as described above.

Experiments of $\mathrm{pH} 10$ affecting hydrogen generation from amino acids fermentation. In this study the comparison of fermentation $\mathrm{pH} 7$ and $\mathrm{pH} 10$ affecting amino acids fermentation was conducted with synthetic amino acids wastewater. The synthetic amino acids wastewater consisted of $0.25 \mathrm{~g} / \mathrm{L}$ L-leucine, L-lysine, Lglutamic acid, L-alanine, L-aspartic acid, L-valine, L-cysteine and L-threonine, respectively. Batch experiments of bio-hydrogen production from synthetic wastewater were conducted in 2 identical reactors, where fermentation $\mathrm{pH}$ was adjusted to 7 and 10, respectively, by adding $6 \mathrm{M} \mathrm{HCl}$ or $6 \mathrm{M} \mathrm{NaOH}$. All other operations were the same as described above.

Experiments of hydrogen production from real protein wastewater. The real wastewater containing high concentration of whey protein was obtained from a milk powder processing plant in Hangzhou, Zhejiang Province, China. The main characteristics of whey protein wastewater in experiments are as follows: $\mathrm{pH} 6.56 \pm$ 0.04 , total chemical oxygen demand (TCOD) $3436 \pm 80 \mathrm{mg} / \mathrm{L}$, protein $2709 \pm 72 \mathrm{mg}$ $\mathrm{COD} / \mathrm{L}$, and carbohydrate $554 \pm 22 \mathrm{mg} \mathrm{COD} / \mathrm{L}$. Comparison of bio-hydrogen production from $\mathrm{pH} 7$ and $\mathrm{pH} 12$ pretreated whey protein wastewater was conducted in 2 identical reactors, where fermentation $\mathrm{pH}$ was controlled at 7 and 10 , respectively, by adding $6 \mathrm{M} \mathrm{HCl}$ or $6 \mathrm{M} \mathrm{NaOH}$. All other operations were the same as described above.

Experiments of protein enzyme hydrolysis. To investigate the effects of pH 12 pretreatment on susceptibility of protein to protease, the protein enzyme hydrolysis experiments were conducted and the protein enzymolysis efficiency was used to express the susceptibility of protein to protease. The experiments were conducted in 2 identical reactors with the $\mathrm{pH} 7$ pretreated protein wastewater (control) and $\mathrm{pH} 12$ pretreated protein wastewater as substrate, respectively. The concentration of pronase $\mathrm{E}$ (model protease, purchased from Merck) in each reactor was $50 \mathrm{mg} / \mathrm{L}$ and the hydrolysis $\mathrm{pH}$ was adjusted to 7 by adding $6 \mathrm{M} \mathrm{HCl}$ or $6 \mathrm{M} \mathrm{NaOH}$ during the entire hydrolysis process. After being flushed with nitrogen gas for $2 \mathrm{~min}$ to remove oxygen, both reactors were capped with rubber stoppers, sealed and placed in an airbath shaker $(140 \mathrm{rpm})$ with the temperature of $36 \pm 1^{\circ} \mathrm{C}$. At set intervals $5 \mathrm{~mL}$ sample was took out and immediately being heat-treated at $100^{\circ} \mathrm{C}$ for $10 \mathrm{~min}$ to inhibit enzyme activity. After cooling down to room temperature the residual protein in sample was precipitated by adding $5 \mathrm{~mL} \mathrm{15 \%}$ trichloroacetic acid (TCA) and the mixture was centrifuged at $4500 \mathrm{rpm}$ for $15 \mathrm{~min}$. The total organic nitrogen concentration in supernatant was determined using a TOC analyzer (TOC-V CPH, Shimadzu, Tokyo, Japan). In this study the enzymolysis efficiency of protein was expressed by the following equation. 


$$
\begin{aligned}
\text { Protein enzymolysis efficiency }(\%) & =\frac{\mathrm{C}_{\text {initial }}-\mathrm{C}_{\text {remaining }}}{\mathrm{C}_{\text {initial }}} \times 100 \\
& =\frac{\mathrm{TN}}{\mathrm{C}_{\text {initial }} \bullet 16 \%} \times 100
\end{aligned}
$$

where $\mathrm{C}_{\text {initial }}$ and $\mathrm{C}_{\text {remaining }}$ is respectively the concentration of protein in wastewater before and after experiment, TN is the concentration of nitrogen in supernatant, and $16 \%$ is the average value of nitrogen content in protein ${ }^{31}$.

Circular dichroism spectrum measurement of protein. The circular dichroism (CD) spectrum of protein was measured on a JASCO J-715 automatic recording spectropolarimeter (Tokyo, Japan) controlled by the JASCO software with a $0.1 \mathrm{~cm}$ quartz cell at room temperature. The sample was diluted to a concentration of $45 \mathrm{mg}$ $\mathrm{BSA} / \mathrm{L}$ and transferred to a quartz cell with a $1 \mathrm{~cm}$ light-path length. Molecular ellipticity was measured in the range of 190-250 nm with a bandwidth of $1 \mathrm{~nm}$ and the scan rate was $50 \mathrm{~nm} / \mathrm{min}$. The distilled water was selected as the blank and was automatically subtracted from each spectrum during scanning. The $\alpha$-helix content of BSA was calculated according to equations (2) and (3) ${ }^{32}$.

$$
M R E=\frac{\text { Observed } C D(m \mathrm{deg})}{C_{p} \bullet n \bullet L}
$$

where MRE is the mean residue ellipticity $\left(\mathrm{deg} \cdot \mathrm{cm}^{2} \cdot \mathrm{dmol}^{-1}\right), \mathrm{C}_{\mathrm{P}}$ is the molar concentration of protein, $n$ is the number of amino acid residues (583 for BSA), and L is the path length of the cell $(\mathrm{mm})$.

$$
a-\operatorname{Helix}(\%)=\frac{-M R E_{208}-4000}{33000-4000} \times 100
$$

where $\mathrm{MRE}_{208}$ is the observed MRE at $208 \mathrm{~nm}, 4000$ is the MRE of the $\beta$-form and random coil conformation cross at $208 \mathrm{~nm}$, and 33000 is the MRE value of a pure $\alpha$ helix at $208 \mathrm{~nm}$.

Fluorescence spectroscopy analysis of protein. Excitation emission matrix (EEM) fluorescence spectroscopy of protein was obtained with a luminescence spectrometry (Fluoromax-4 Spectrofluorometer, HORIBA Scientific, France). Prior to the EEM test, the sample was filtered through a $0.45 \mu \mathrm{m}$ hydrophilic filtration membrane and diluted to an approximate concentration. To get the fluorescence of EEM, the excitation and emission wavelengths were gradually increased from 200 to $400 \mathrm{~nm}$ at $2 \mathrm{~nm}$ increments and 250 to $450 \mathrm{~nm}$ at a $5 \mathrm{~nm}$ step, respectively.

Raman spectrum analysis of protein. Before Raman measurements, the $\mathrm{pH} 7$ (control) or $\mathrm{pH} 12$ pretreated synthetic protein wasterwaters was frozen at $-20^{\circ} \mathrm{C}$ and then lyophilized. Raman spectrum was recorded on a Dilor-Jobin Yvon-Spex Raman spectrometer equipped with an Olympus BX 40 system microscope with $100 \times$ objectives. A He-Ne laser system with excitation line at $632.8 \mathrm{~nm}$ and an excitation power of $6 \mathrm{~mW}$ was used in the measurements. The recording range was $200-1800 \mathrm{~nm}$ with a resolution of $1.2 \mathrm{~cm}^{-1}$ and the spectrum was the accumulated averages of 3 exposures at room temperature $\left(25^{\circ} \mathrm{C}\right)$. The average spectrum was smoothed by a $5 \mathrm{~cm}^{-1}$ filter and was corrected by a polynomial baseline using LabSpec (Dilor-Jobin Yvon-Spex, France) software. To calculate the corresponding content of the protein conformation, spectra shown in the main text were normalized against the phenylalanine band at $1004 \mathrm{~cm}^{-1}$ as its intensity (set as 1000) was unaffected by conformational changes in protein according to the leaterature ${ }^{18}$. The curve fitting of Raman spectrum was made by Origin 8.5 (Origin, USA) using multiple peak fit (Gaussian model).

Other analytical methods. The gas component was measured using a gastight syringe $(0.2 \mathrm{~mL}$ injection volume) and a gas chromatograph (GC112A, China) equipped with a thermal conductivity detector (TCD) and a $4 \mathrm{~mm} \times 2 \mathrm{~m} \mathrm{GDX}-102$ stainless column ${ }^{13}$. The temperatures of the injection port, column, and detector were set at 40 , 40 and $80^{\circ} \mathrm{C}$, respectively. Nitrogen was used as the carrier gas at a flow rate of $30 \mathrm{~mL} /$ min. The $\mathrm{pH}$ value was measured by a $\mathrm{pH}$ meter. The determinations of protein, $\mathrm{SS}$, VSS, and volatile fatty acids (VFA) were the same as those described previously ${ }^{33}$. The total VFA was calculated as the sum of measured acetic, propionic, n-butyric, isobutyric, $\mathrm{n}$-valeric, and iso-valeric acids. The detailed analytical procedures of fluorescence in situ hybridization (FISH), real-time polymerase chain reaction (PCR), protease, oxaloacetate transcarboxylase (OAATC), NADH-Fd reductase, and hydrogenase activities are presented in Supplementary information.

Statistical analysis. All tests were conducted in triplicate and the results were expressed as mean \pm standard deviation. An analysis of variance (ANOVA) was used to test the significance of results and $p<0.05$ was considered to be statistically significant.

1. Brentner, L. B., Peccia, J. \& Zimmerman, J. B. Challenges in Developing Biohydrogen as a Sustainable Energy Source: Implications for a Research Agenda. Environ. Sci. Technol. 44, 2243-2254 (2010).

2. Xiao, B., Han, Y. \& Liu, J. Evaluation of biohydrogen production from glucose and protein at neutral initial pH. Int. J. Hydrog. Energy 35, 6152-6160 (2010).
3. Zhu, H. \& Beland, M. Evaluation of alternative methods of preparing hydrogen producing seeds from digested wastewater sludge. Int. J. Hydrog. Energy 31, 1980-1988 (2006).

4. Wang, Y., Sheng, G., Shi, B., Li, W. \& Yu, H. A Novel Electrochemical Membrane Bioreactor as a Potential Net Energy Producer for Sustainable Wastewater Treatment. Sci. Rep. 3, 1864 (2013).

5. Lee, H. S., Salerno, M. B. \& Rittmann, B. E. Thermodynamic evaluation on $\mathrm{H}(2)$ production in glucose fermentation. Environ. Sci. Technol. 42 (2008).

6. Li, C. L. \& Fang, H. H. P. Fermentative hydrogen production from wastewater and solid wastes by mixed cultures. Crit. Rev. Environ. Sci. Technol. 37, 1-39 (2007).

7. Ramsay, I. R. \& Pullammanappallil, P. C. Protein degradation during anaerobic wastewater treatment: derivation of stoichiometry. Biodegradation 12, 247-257 (2001).

8. Wu, J., Wang, Z. \& Xu, S. Preparation and characterization of sericin powder extracted from silk industry wastewater. Food Chem. 103, 1255-1262 (2007).

9. Herman, R., Gao, Y. \& Storer, N. Acid-induced unfolding kinetics in simulated gastric digestion of proteins. Regul. Toxicol. Pharmacol. 46, 93-99 (2006).

10. Carbonaro, M., Maselli, P. \& Nucara, A. Relationship between digestibility and secondary structure of raw and thermally treated legume proteins: a Fourier transform infrared (FT-IR) spectroscopic study. Amino Acids 43, 911-921 (2012).

11. Bai, M., Cheng, S. \& Chao, Y. Effects of substrate components on hydrogen fermentation of multiple substrates. Water Sci. Technol. 50, 209-216 (2004).

12. Akutsu, Y., Lee, D. Y., Li, Y. Y. \& Noike, T. Hydrogen production potentials and fermentative characteristics of various substrates with different heat-pretreated natural microflora. Int. J. Hydrog. Energy 34, 5365-5372 (2009).

13. Zhao, Y., Chen, Y., Zhang, D. \& Zhu, X. Waste Activated Sludge Fermentation for Hydrogen Production Enhanced by Anaerobic Process Improvement and Acetobacteria Inhibition: The Role of Fermentation pH. Environ. Sci. Technol. 44, 3317-3323 (2010).

14. Friedli, G.-L. Interaction of deamidated soluble wheat protein (SWP) with other food proteins and metals. Doctoral thesis, University of Surrey. 193-199 (1996). http://epubs.surrey.ac.uk/2204/ [2012-8-30].

15. Bhattacharya, M., Jain, N., Bhasne, K., Kumari, V. \& Mukhopadhyay, S. pHinduced Conformational Isomerization of Bovine Serum Albumin Studied by Extrinsic and Intrinsic Protein Fluorescence. J. Fluoresc. 21, 1083-1090 (2011).

16. Kristo, E., Hazizaj, A. \& Corredig, M. Structural changes imposed on whey proteins by UV irradiation in a continuous UV light reactor. J. Agric. Food Chem. 60, 6204-6209 (2012)

17. Nakamura, K. et al. Conformational changes in seventeen cystine disulfide bridges of bovine serum albumin proved by Raman spectroscopy. Febs Lett. 417, 375-378 (1997).

18. Li Chan, E. C. Y. The applications of Raman spectroscopy in food science. Trends Food Sci. Technol. 7, 361-370 (1996).

19. Hubert Blusson., Henri Petitdemange. \& Gay, R. A new, fast, and sensitive assay for NADH-ferredoxin oxidoreductase detection in clostridia. Anal. Biochem. 110, 176-181 (1981)

20. Vignais, P. M., Billoud, B. \& Meyer, J. Classification and phylogeny of hydrogenases. Fems Microbiol. Rev. 25, 455-501 (2001).

21. Wood, H. G., Jacobson, B., Gerwin, B. I. \& Northrop, D. B. Oxalacetate transcarboxylase from Propionibacterium. Methods Enzymol. 8, 215-230 (1969).

22. Yu, P. Q. Protein secondary structures (alpha-helix and beta-sheet) at a cellular level and protein fractions in relation to rumen degradation behaviours of protein: a new approach. Br. J. Nutr. 94, 655-665 (2005).

23. Carter, D. C. \& Ho, J. X. Structure of serum albumin. Adv. Protein Chem. 45 153-203 (1994).

24. Shaikh, S. M. T., Seetharamappa, J., Kandagal, P. B., Manjunatha, D. H. \& Ashoka, $\mathrm{S}$. Spectroscopic investigations on the mechanism of interaction of bioactive dye with bovine serum albumin. Dyes Pigment. 74, 665-671 (2007).

25. Li, R. et al. Effect of $\mathrm{pH}$ on the gel properties and secondary structure of fish myosin. Food Chem. 121, 196-202 (2010).

26. Chodankar, S., Aswal, V. K., Kohlbrecher, J., Vavrin, R. \& Wagh, A. G. Structural evolution during protein denaturation as induced by different methods. Phys. Rev. E 77 (2008)

27. Bertrand-Harb, C., Baday, A., Dalgalarrondo, M., Chobert, J. M. \& Haertle, T. Thermal modifications of structure and co-denaturation of alpha-lactalbumin and beta-lactoglobulin induce changes of solubility and susceptibility to proteases. Nahrung 46, 283-289 (2002).

28. Piatkevich, K. D. et al. Extended Stokes Shift in Fluorescent Proteins: Chromophore-Protein Interactions in a Near-Infrared TagRFP675 Variant. Sci. Rep. 3, 1847 (2013).

29. Tanisho, S., Kuromoto, M. \& Kadokura, N. Effect of CO2 removal on hydrogen production by fermentation. Int. J. Hydrog. Energy 23, 559-563 (1998)

30. Xu, K., Liu, H. \& Chen, J. Effect of classic methanogenic inhibitors on the quantity and diversity of archaeal community and the reductive homoacetogenic activity during the process of anaerobic sludge digestion. Bioresour. Technol. 101, 2600-2607 (2010).

31. Miron, Y., Zeeman, G., Van Lier, J. B. \& Lettinga, G. The role of sludge retention time in the hydrolysis and acidification of lipids, carbohydrates and proteins during digestion of primary sludge in CSTR systems. Water Res. 34, 1705-1713 (2000). 
32. Khan, S. N. et al. Interaction of mitoxantrone with human serum albumin: Spectroscopic and molecular modeling studies. Eur. J. Pharm. Sci. 35, 371-382 (2008).

33. Yuan, H. et al. Improved bioproduction of short-chain fatty acids (SCFAs) from excess sludge under alkaline conditions. Environ. Sci. Technol. 40, 2025-2029 (2006).

\section{Acknowledgments}

This work was financially supported by the National Natural Science Foundation of China (Nos. 51178324 and 51278354), and National Key Technology Research and Development Program of the Ministry of Science and Technology of China (No. 2012BAC11B04).

\section{Author contributions}

N.D.X. carried out the experiments and wrote the paper, Y.G.C. conceived the study design and co-wrote the paper, A.H.C. analyzed the data, L.Y.F. characterized the protein structure. All authors contributed to the scientific planning and discussions.

\section{Additional information}

Supplementary information accompanies this paper at http://www.nature.com/ scientificreports

Competing financial interests: The authors declare no competing financial interests. How to cite this article: Xiao, N.D., Chen, Y.G., Chen, A.H. \& Feng, L.Y. Enhanced Bio-hydrogen Production from Protein Wastewater by Altering Protein Structure and Amino Acids Acidification Type. Sci. Rep. 4, 3992; DOI:10.1038/srep03992 (2014).

\section{(c) (i) (5) $\ominus$ This work is licensed under a Creative Commons Attribution-}

BY nc No NonCommercial-NoDerivs 3.0 Unported license. To view a copy of this license, visit http://creativecommons.org/licenses/by-nc-nd/3.0 